\title{
Sustainable water management: a case study at the Jacksonville Zoo
}

\author{
M. Fagan ${ }^{1}$, C. Brown ${ }^{1}$ \& B. Chabot ${ }^{2}$ \\ ${ }^{I}$ School of Engineering, University of North Florida, Florida, USA \\ ${ }^{2}$ Jacksonville Zoo and Gardens, Jacksonville, Florida, USA
}

\begin{abstract}
Due to its status as a non-profit organization, the Jacksonville Zoo and Gardens (Zoo) provides a great landscape for implementing a sustainable water management system since it is always seeking ways to reduce costs and improve the environment. Over the last few years, the renovation and construction of new exhibits, have led to a higher visitation rate and concomitant increased cost and water demands. This study describes recent efforts by the Zoo to develop sustainable water resource solutions while creating interesting environmental education exhibits. By creating a system that allows for the capture and treatment of stormwater, precipitation, and water used for exhibits, the Zoo will have the ability to register significant financial savings as well as secure conservation of a valuable natural resource.
\end{abstract}

Keywords: water treatment, zoo, wetland, sand filter, irrigation, water management, sustainable, storm water reuse.

\section{Introduction}

The advent of the modern zoo occurred during the early nineteenth century [1]. Zoos were originally the destination for visitors to observe animals in cages and mostly in exhibits that were not consistent with the native habitats that the animals were bred. Nearly everyone who came to watch the exotic animals was a "lay person" in the sense that virtually none had formal training in zoology [1]. However, today's zoos are a center for scientific studies of all kinds. Science at zoos can be challenging and there are many obstacles, such as regulations and financials. Yet despite these obstacles the zoological garden contributed to the rise of ecological thinking as well as to the formation of ethology as a scientific 
discipline [1]. Studies can range from animal husbandry [2] to ethics [3] and to microbiology [4]. Recently, there has been a trend of zoos evaluating water resources and water quality improvement projects [5]. The Jacksonville Zoo and Gardens is joining this movement to improve their water management system.

The Jacksonville Zoo and Gardens (Zoo) has been in operation since 1914 starting with just one red deer fawn and has since grown to house approximately 1,800 animals and 1,000 varieties of plants on its current 118 acres [6,7]. With over 650,000 visitors per year, the Zoo uses approximately 379 million liters of water per year (five year average 2005 to 2009) [7]. Water is obtained from four active wells (screened in the limestone Floridan Aquifer System) and augmented by purchased potable water from the Jacksonville Electric Authority (JEA). With the growing concern over aquifer depletion and pressure from the local water management district, the Zoo has reduced the quantity of water pumped from its wells, and relies on purchasing the majority of the water used on the grounds. This alternative comes at a high cost; in 2009 approximately $\$ 250,000$ was spent on water and sewer fees. Anticipating continued growth of exhibits and increased visitation, the Zoo is anxious to find ways of reducing this cost and developing a more sustainable water conservation system. Currently, the Zoo has implemented a variable speed pumping system tied into a wet detention system for irrigation of the parking area. They also allow many open air exhibits to have their basins filled by stormwater and precipitation. However, even with these methods, a large percentage of the stormwater and precipitation are not captured by means that permit alternatives for water reuse. Also, many of the Zoo gardens contain varieties of plants that are sensitive to the use of untreated stormwater runoff. The water management system currently in place consists of closed conveyance systems and wet detention basins, which are treated per Saint Johns River Water Management District standards, and discharged into the bordering Trout River.

\section{Collection}

As part of on-going research efforts at the Zoo, the University of North Florida provided an assessment of water reclamation and stormwater reuse opportunities. Several candidate water sources were identified. These were considered ideal for collection, treatment and reuse, and are discussed further in this paper. These sources include direct precipitation, stormwater runoff, and backwash water (from existing exhibit filters).

\subsection{Precipitation}

Precipitation data for a 10 year period beginning in 1999 was obtained from the office of the State Climatologist at Florida State University's Florida Climate Center. The Jacksonville International Airport rain gauge station $\left(30^{\circ} 30^{\prime} \mathrm{N} 81^{\circ}\right.$ $42^{\prime} \mathrm{W}$ ) was chosen to represent the Zoo's precipitation due to the airport's close proximity to the Zoo. By averaging the monthly rainfall data, wet and dry 
months were established. Also the yearly sums and averages of the rainfall data were calculated to normalize any meteorological anomalies, such as a major hurricane year or drought, to determine the average annual precipitation for the Zoo. This value is calculated at approximately 50 inches per year; however the average annual evaporation rate is estimated to be as much as 45 inches, leaving an average of at least 5 inches per year available for harvesting. It was also determined that summer thunderstorms provide a large amount of precipitation in short duration that is greater than evaporation rate so these storms can also be targeted as a source of water collection and reuse. For smaller areas requiring irrigation, rain barrels are recommended to collect the precipitation. The rain barrels can be equipped with small sand filters to provide cost effective treatment. This treated water can then get distributed to nearby areas to meet irrigation demands of the many gardens at the Zoo.

\subsection{Runoff}

To complete an accurate runoff analysis, average runoff was determined using the SCS method (U.S. Department of Agriculture Soil Conservation Service). This method requires the use of a runoff curve number $(\mathrm{CN})$. The $\mathrm{CN}$ "is a function of land use, antecedent soil moisture, and other factors affecting runoff and retention in a watershed" [8]. Both 10-year and 25-year rainfall data was collected for the nearby Jacksonville International Airport. Data for the last 25 years was segregated by month and then statistics were calculated for each month including 10 percentile, 50 percentile (median), $90 \%$ percentile, and the mean. For this analysis, the 50 percentile was used to estimate available rainfall and runoff at the Zoo. The 10 percentile was also evaluated to determine minimum stormwater that could be available for reuse even in mostly dry periods. Approximately 12 acres of the Zoo is already covered with ponds. These pond areas get 40 to 60 inches of precipitation per year that is used by the Zoo to maintain exhibit water levels. Since this runoff is already used by the Zoo it cannot be captured for additional purposes. Therefore, available runoff does not include this component. Out of the remaining runoff $(239,000,000$ liters), it is assumed that up to $15 \%$ of this value could potentially be captured and reused by the Zoo for various water resources functions without effecting nearby ecosystems or existing Zoo activities. For the median year, this could amount to as much as $36,000,000$ liters per year or almost $10 \%$ of the Zoo's annual demand.

The model assumed that storm water runoff would be calculated assuming the curve number had an average antecedent moisture condition (AMC II). The land use was divided into three categories: ponds at normal water level, paved parking lots/roofs, and fair condition grass cover. The weighted curve number for the Zoo model was calculated to be 85 . Using this curve number and the 25 year median monthly rainfall values for the SCS method, TR-55 method was applied to calculate the surplus runoff for the Zoo basin. Besides harvesting of Zoo stormwater, additional sources of exhibit water were investigated. 


\subsection{Exhibits}

Several exhibits have filtration systems that require backwash daily or several times per week. The source of this water is exclusively potable water and is discharged into the city's sanitary sewer system. This backwashing procedure uses approximately 3,000,000 liters of water per month. Due to the large quantity of water used by the backwashing (almost $10 \%$ of the Zoo water demand), it is a great candidate for collection and reuse. Most of these filters are located near storm sewer systems that convey water to wet detention facilities. By re-routing this water from entering the sanitary sewer system to flowing into the storm sewer system, this water is now available for treatment and redistribution. This concept is consistent with other Zoo owners and operators interested in water conservation [9].

\section{Treatment}

In order to use the collected water in exhibits or for irrigation around the Zoo, treatment is required $[10,11]$. Many methods of water treatment are viable, however two methods, slow sand filtration and constructed wetlands, are outlined in this case study. By integrating these two methods together, a higher quality of water can be achieved.

\subsection{Sand filtration}

Sand filters have been used extensively to reduce pollutant loads in water [12, 13]. Sand filters can either be placed below the water source or in the bank next to or in front of the water source. The most common and often most preferred configuration is the filter being placed below the water needing to be treated. This method uses gravity to "pull" water through the filter versus a using a pumping system. A basic design of the gravity filter uses an open basin filled partially with sand that drains at the bottom, where the pressure filter is placed in a closed basin, which contains sand and other granular mixtures, and water is forced through under pressure [14]. The gravity filter is affiliated with term slow sand filtration or biological filtration. As the water flows through a sand filter, a biological "shield" forms on the surface. This "shield", known as schmutzdecke, contains natural organisms that consume the pathogens and disease-causing organisms that were living in the untreated water. The filter will "operate" for approximately two weeks to three months before needing maintenance cleaning and this time line is dependent on the type of sand, time of year, pre-treated water quality and filter loading $[15,20]$.

When retrofitting a system, as in the Jacksonville Zoo case study, elevations and water table often don't allow for gravity filters, therefore a pump system must get implemented. For the Zoo, a large sand filtration basin will be placed along an existing drainage swale, which will allow the storm sewer system to continue to convey water towards the treatment. The water will collect into a sump area to get pumped through the sand filter and discharge into the existing 


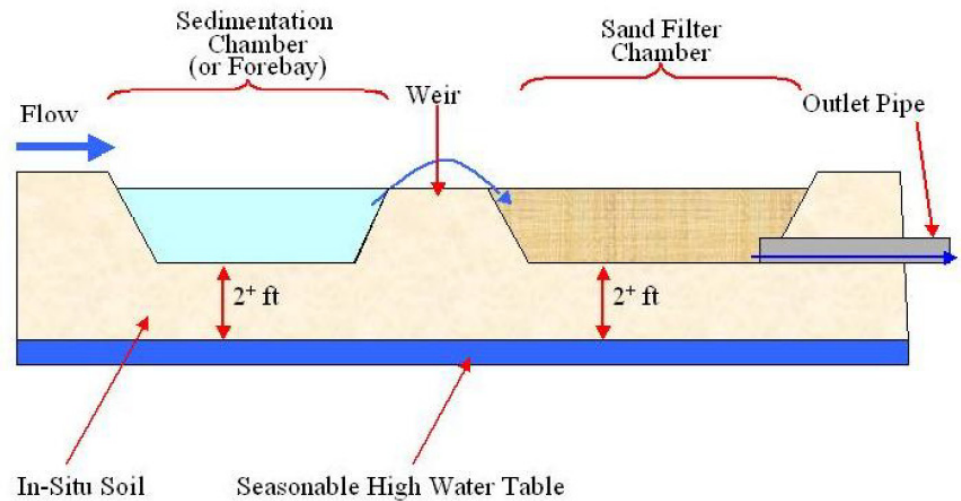

Figure 1: $\quad$ Open sand filtration basin example [16, 17].

drainage swale. From the drainage swale, the partially treated water will continue to the next phase of treatment, the constructed wetland. Figure 1 depicts the conceptual design layout for the Zoo.

\subsection{Constructed wetland}

Constructed wetlands are becoming more popular in recent years due to aesthetic benefits and the maintenance ease. Depending on the size of the wetland, the treatment can reach very high levels [18]. Several Zoos, including San Diego Zoo, North Carolina Zoo, and Beijing Zoo have implemented several constructed wetland systems to treat the wastewater from exhibits; this has helped with odours and created aesthetically pleasing areas around the zoo [19]. There are a few options for the wetland design, but for the Zoo case study, a multi-cell wetland is the most feasible. The multi-cell wetland works best in relatively flat, constrained areas since extra storage is not required in this design. In the Zoo configuration, the wetland cells will be placed along an existing wet detention facility, which provides treatment and attenuation before discharge into the Trout River. This again allows for the use of the existing storm sewer system to route the water from the sand basin/drainage swale to the wetland system. By positioning the wetland cells along the detention pond, this allows for excess water during design storms to overtop into the pond. The storm water will flow through the wetland system, to a storage basin. From the storage basin, the treated water can get pumped to needed areas around the zoo. Figure 2 provides the conceptual design alternative for the Zoo constructed wetland treatment system.

\section{Summary}

The Jacksonville Zoo and Gardens has many opportunities to conserve and create a sustainable environment. By starting with improving the water 


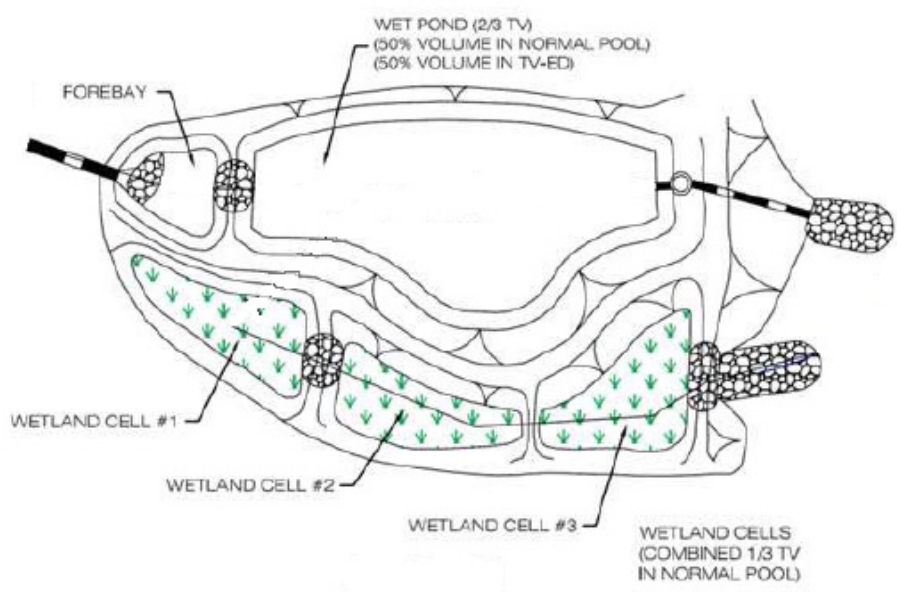

Figure 2: $\quad$ Constructed Wetland Cells along Wet Detention Pond [16].

management system, they will see considerable cost and water savings. Since the zoo is a non-profit agency, some of the construction costs of the sand and wetland treatment systems can get offset by grants and private donations as well as accrued savings realized from the new projects. And an additional benefit of the treatment system would be in creating an educational exhibit for the zoo visitors. By adding native plant species around the area, and proper signing, zoo visitors will increase their awareness regarding water treatment with natural resources. Though this case study focused on the design of one system, this system can be implemented throughout the zoo at varying scales dependent on the drainage areas, and exhibits providing treatable water. With further expansion and new exhibits, sustainable design can be included in the design. Design work on these projects is underway and will be discussed in future articles.

\section{References}

[1] Hochadel, O. (2011). Watching exotic animals next door: "scientific" observations at the zoo (ca. 1870-1910). Science in Context, 24(2), 183.

[2] Ben-Ari, E. T. (2001). What's new at the zoo? Bioscience, 51(3), 172.

[3] Clayton, P. H. (1996). Ethics on the ark: Zoo, animal welfare, and wildlife conservation. American Scientist, 84(5), 500.

[4] Garijo, M. M., Ortiz, J. M., \& de Ibáñez, M. R. R. (2004). Helminths in a giraffe (giraffa camelopardalis giraffa) from a zoo in spain. The Onderstepoort Journal of Veterinary Research, 71(2), 153. 
[5] Chen, Q., Shan, B., Yin, C., \& Hu, C. (2007). An off-line filtering ditchpond system for diffuse pollution control at Wuhan City Zoo. Ecological Engineering, 30(4), 373-380. DOI: 10.1016/j.ecoleng.2007.04.008

[6] Jacksonville Zoological Gardens. www.jacksonvillezoo.org/about

[7] Chabot, B. Personal communication, 2010-2011, Director of Facilities, Jacksonville Zoological Gardens. Jacksonville, Florida, USA.

[8] Mays, L. W. (2005). Water resources engineering. Hoboken: J. Wiley.

[9] Fedler, C. B. (2005). Recycling water saves future drinking supplies. Biocycle, 46(2), 50.

[10] Chen, Q., Shan, B., Yin, C., \& Hu, C. (2007). Two alternative modes for diffuse pollution control in Wuhan City Zoo. Journal of Environmental Sciences, 19(9), 1067-1073. DOI: 10.1016/S1001-0742(07)60174-0

[11] Bester, K., \& Schäfer, D. (2009). Activated soil filters (bio filters) for the elimination of xenobiotics (micro-pollutants) from storm- and waste waters. Water Research, 43(10), 2639-2646. DOI: 10.1016/j.watres.2009.03.026

[12] Cho, K. W., Song, K. G., Cho, J. W., Kim, T. G., \& Ahn, K. H. (2009). Removal of nitrogen by a layered soil infiltration system during intermittent storm events. Chemosphere, 76(5), 690-696. doi: DOI: 10.1016 /j.chemosphere.2009.03.025

[13] Van Riper, C., \& Geselbracht, J. (1997). Water reclamation and reuse. Water Environment Research [H.W.Wilson - AST], 69, 554.

[14] Katsioloudis, P. (2009). Water Treatment: Keeping it Pure. The Technology Teacher, 68(7), 10-15. Retrieved July 25, 2010, from ProQuest Education Journals. (Document ID: 1699562751)

[15] Binnie, C., Kimber, M., \& Smethurst, G. (2009). Basic water treatment. London: Thomas Telford.

[16] Virginia DCR Stormwater Design Specification No. 13. (2011) Constructed Wetlands.

[17] North Carolina Division of Water Quality. (2007) Stormwater Best Management Practices. Ch. 9. Stormwater Wetland, Ch. 11 Sand Filter

[18] Cooper, P. (2009). What can we learn from old wetlands? lessons that have been learned and some that may have been forgotten over the past 20 years. Desalination, 246(1-3), 11-26. DOI: 10.1016/j.desal.2008.03.040

[19] Jiang, Z., \& Xinyuan, Z. (1998). Treatment and utilization of wastewater in the Beijing zoo by an aquatic macrophyte system. Ecological Engineering, 11(1-4), 101-110. DOI: 10.1016/S0925-8574(98)00026-3

[20] Slow sand filtration facility helps lower costs. (1997, March). The American City \& County, 112(3), 43-44. Retrieved July 25, 2010, from ABI/INFORM Global. (Document ID: 11261302). 